\title{
Environmentally-safe $\mathrm{scCO}_{2} P$. pinaster branches extracts: Composition and properties
}

\author{
Marisa C. Gaspar ${ }^{\mathrm{a}}$, Hermínio C. de Sousa ${ }^{\mathrm{a}}$, Inês J. Seabra ${ }^{\mathrm{b} *}$, Mara E.M. Braga ${ }^{\mathrm{a} * *}$ \\ ${ }^{a}$ CIEPQPF, Department of Chemical Engineering, University of Coimbra, Rua Sílvio Lima, Pólo II, Pinhal De Marrocos, $3030-790$ Coimbra, Portugal \\ ${ }^{\mathrm{b}}$ Bioengineering Department, Lehigh University, 111 Research Drive, Bethlehem, PA, 18015, United States
}

\section{A R T I C L E I N F O}

\section{Keywords:}

Pine branches

Abietadiene

Antioxidant

Acetylcholinesterase inhibition activity

\begin{abstract}
A B S T R A C T
Considering the vast array of compounds that plants manufacture that help protect them against insects' attacks, plant raw materials are a potential source of future insecticides/larvicides. In this work, volatiles from maritime pine (Pinus pinaster) branches, a pruning residue, were extracted by supercritical carbon dioxide $\left(\mathrm{scCO}_{2}\right)$, and also by hydrodistillation for comparison purposes. The volatiles naturally emitted from the pine branches were identified as well. Experimental design results showed higher extraction yields (up to 6\%), when $\mathrm{scCO}_{2}$ density and temperature increased, while the inverse occurred for total phenolic contents (1.2-3.3\% GAE, gallic acid equivalents). Emitted volatiles from the branches were mainly $\alpha$-pinene, $\beta$-pinene, $\beta$-myrcene, limonene, and $\beta$ caryophyllene. In general, the volatile profiles of the $\mathrm{scCO}_{2}$ and hydrodistillation extracts were quite similar, revealing abietadiene, the precursor of abietic acid, as the main compound. Oxidation inhibitions of $\sim 42-59 \%$ were obtained for the $\mathrm{scCO}_{2}$ extracts in the $\beta$-carotene assay. The acetylcholinesterase inhibitory activity assay revealed the potential of these extracts to have insecticidal/larvicidal activity, with $\mathrm{IC}_{50}$ values of $2.8-10.7 \mathrm{mg} /$ mL. Overall, these extracts may be applied in environmentally-safe insect/larvae control strategies, in formulations that benefit from the presence of antioxidants.
\end{abstract}

\section{Introduction}

Natural compounds with repellent or insecticidal activity may be solvent-extracted from a wide number of plants, including those from the pine species. Most of them correspond to the plant's volatile fraction, which is a complex blend of hundreds of compounds, mainly containing 5-20 carbon atoms, that protect the plant from high temperature stress and mediate interaction with other plants and organisms [1]. Studies from different plants, including coniferous and deciduous species, have reported terpenes/terpenoids, fatty acid esters, and aldehydes as the main emitted volatiles, which play significant roles in several ecosystem-level processes [2]. In particular, monoterpenes, which are widely known constituents of conifers and citrus plants, can be easily detected by insects, and therefore act as toxins, as feeding and oviposition deterrents, or as attractants for those insects [3]. Although their commercialization is still scarce, volatile oils obtained from a wide range of plant species have also revealed insecticidal, antifungal and/or repellent activities towards several insects, presenting lower impacts on ecosystems, environment and health when compared to synthetic insecticides. Among promising plant species studied to control insects and microorganisms, Eucalyptus spp., Ocimum spp., Cymbopogon spp. and many citrus fruits have been strongly investigated [3,4]. In the case of the Pinus spp., some monoterpenes are preferentially present, including $\alpha$-pinene, $\beta$-pinene, limonene and $\alpha$-terpineol [2]. In particular, abietic acid is produced by conifer species as a defensive secretion against attacks by insects and other pathogens [5]. Other compounds naturally emitted by pine species, such as $\beta$-pinene and limonene, act as repellents [2,3]. Furthermore, $\beta$-pinene and its analogues have already been reported to have antifeedant and antimicrobial activities [6]. These compounds may potentially be extracted from a number of residues that derive from pine industries, including wood pieces, bark, cones, branches, and needles. While the most common utilization of these residues has been for energy production [7,8], they are also applied in the biorefinery context, being valorized for the production of biofuels and biochemicals [8-10]. However, only a few studies have focused on the investigation of volatiles emitted from pine tree branches, which is an easily gathered pruning residue [11].

Despite the promising potential of natural resources, the use of synthetic insecticides is presently the most common strategy to control insect pests in agriculture and forestry. Yet, their lack of selectivity, repeated use and residual contamination have been poisoning nontargeted organisms and increasing resistance in insects [12,13]. As a

\footnotetext{
* Corresponding authors.

E-mail addresses: marisagaspar@eq.uc.pt (M.C. Gaspar), hsousa@eq.uc.pt (H.C. de Sousa), ijs218@lehigh.edu (I.J. Seabra), marabraga@eq.uc.pt (M.E.M. Braga).
} 
consequence, synthetic insecticides pose a risk both to the environment and to public health $[14,15]$. Commonly used synthetic insecticides, like organophosphates and carbamates, have their mechanism of toxicity based on the inhibition of acetylcholinesterase (AChE) [16]. These compounds can cause similar toxic acute effects and for organophosphates the effects are related to the irreversible AChE inhibition $[17,18]$. In insects, the enzyme AChE hydrolyses the neurotransmitter acetylcholine, a chemical involved in the neuronal excitement at the postsynaptic membrane. The acetylcholine accumulation produces a rapid twitching of voluntary muscles, eventually paralysis, and ultimately death of the insect [19]. These insecticides are widely used to manage insects, considered as pests, in agriculture and in forestry, in spite of alternative strategies, such as the application of natural insecticides.

The AChE inhibition assay has been applied to several plant-based compounds in order to evaluate their bioactivity against microorganisms and insects. Examples are found in M. pinhata seed-derived compounds that presented potential larvicidal effects [20]. Inhibitory effects of AChE were also observed for compounds such as $\beta$-pinene and carvacrol, which can be related to their larvicidal activity [21]. Extracts from Urginea maritime bulbs revealed insecticidal effect on rice weevil, as confirmed by the AChE inhibition [22].

In this way, pruning residues from Pinus spp. could also be used to recover bioactive compounds for the management of insects/larvae that pose a threat in agroforestry practices, a strategy that would be in line with the principles of biorefinery. Therefore, the aim of this study was the identification of volatiles naturally emitted from a forestry residue, $P$. pinaster branches, and the comparison of those compounds with the ones obtained by supercritical carbon dioxide $\left(\mathrm{scCO}_{2}\right)$ extraction and hydrodistillation (HD). The extractions were performed according to an experimental design, and the extracts were evaluated regarding their total extraction yield, volatile composition, total phenolic content, as well as antioxidant and AChE inhibitory activities.

\section{Materials and methods}

\subsection{Raw material}

Pruning residues (young branches) were collected from $P$. pinaster trees of a pine forest in Coimbra (Portugal), in September of 2017. The pruning of trees in the vicinity of other trees is mandatory nowadays in Portugal, following recent Portuguese legislation that requires that the distance between treetops must be at least $4 \mathrm{~m}$ [23]. Valorisation strategies of those pruning residues are then being seek, following a general eco-sustainable approach of converting wastes into resources. Raw material was milled (cross beater mill, Retsch, Germany) in order to obtain a particle size smaller than $2 \mathrm{~mm}$, and stored at $-20^{\circ} \mathrm{C}$. Before the extraction experiments, the moisture content of $P$. pinaster branches was evaluated by thermogravimetric analysis (TGA, TA Instruments, model Q500), in triplicate, to report yield results on a dry weight basis (wt \%, d.b). Samples were heated at $10^{\circ} \mathrm{C} / \mathrm{min}$, from $25^{\circ} \mathrm{C}$ up to $600^{\circ} \mathrm{C}$, under a nitrogen atmosphere.

\subsection{Chemicals}

Chemicals, solvents and standards used for the extractions and characterization methods were: carbon dioxide ( $\geq 99.5 \%)$ from Praxair; dichloromethane ( $\geq 99.9 \%$, HPLC grade), chloroform ( $\geq$ 99\%), methanol ( $\geq 99.9 \%$, HPLC grade), hydrochloric acid ( $\mathrm{HCl}, 37 \%$, p.a.) and ethyl acetate ( $\geq 99.9 \%$, HPLC grade) from Carlo Erba (Val de Reuil, France); Folin-Ciocalteu's reagent from PanReac (Barcelona, Spain); sodium carbonate from Pronalab (Lisbon, Portugal); gallic acid (97.5-102.5\%), $\beta$-carotene (Type I, 95\% UV), linolenic acid ( $\geq 99 \%$ ), Tween 40, acetylcholinesterase (AChE, Type VI-S, $500 \mathrm{U} / \mathrm{mg}$ protein), 5,5'-dithiobis[2-nitrobenzoic acid] (DTNB, $\geq 98 \%$ ), acetylthiocholine iodide (AChI, $\geq 98 \%$ ), butylated hydroxyanisole (BHA, $\geq 98.5 \%$ ), ethanol ( $\geq 99.8 \%$, p.a.) and tris(hydroxymethyl)aminomethane (Tris Buffer) from Sigma-Aldrich (Sintra, Portugal); butylated hydroxytoluene (BHT, 99\%) from Acrós Organics (Geel, Belgium); phosmet (Foslete ${ }^{\circledast}$ ) from Sipcam - Quimagro (Lisbon, Portugal), and dimethoate (Perfekthion $^{\circledR}$ ) from Portuguese BASF (Porto, Portugal).

\subsection{Extraction of volatiles}

\subsubsection{Solid-phase microextraction (SPME)}

SPME was used to evaluate the volatile compounds that are naturally emitted from $P$. pinaster branches, and to compare and correlate these with those obtained by $\mathrm{scCO}_{2}$ extraction and by HD. Briefly, the intact branches were cut into one portion per sample, and transferred to an empty flask in order to ensure a $1 / 100(\mathrm{w} / \mathrm{v})$ ratio, i.e., $1.0 \mathrm{~g}$ of sample per $100 \mathrm{~cm}$ [3] of air. Samples were subjected to minimal handling to avoid modifications of the volatiles emitted from the pine branches, because some enzymatic processes begin after plant tissue disruption and consequently many more volatiles are therefore emitted (depending on the level and time elapsed since damage) [24]. Volatiles were adsorbed for $5 \mathrm{~min}$ using a $65 \mu \mathrm{m}$ polydimethylsiloxane/divinylbenzene (PDMS/DVB) coated fiber (StableFlex, Sigma-Aldrich) in the headspace mode $\left(35^{\circ} \mathrm{C}\right)$, without the use of any solvent. Experimental conditions of time (1-15 $\mathrm{min})$ and temperature $\left(25-40{ }^{\circ} \mathrm{C}\right)$ were previously optimized. This optimization was performed by increasing the temperature inside the flask from $25^{\circ} \mathrm{C}$ to $40{ }^{\circ} \mathrm{C}$, over a time period of $15 \mathrm{~min}$, and by analyzing the successive GC/MS chromatograms (at 1,5 , and $15 \mathrm{~min}$ ). The selected conditions $\left(5 \mathrm{~min}\right.$ and $35^{\circ} \mathrm{C}$ ) allowed the adsorption of the pine volatiles by the fiber, while avoiding their thermal degradation. Five minutes was found enough to clearly identify the emitted volatiles, contrarily to shorter adsorption times. Coincidently, this time period corresponded to $35{ }^{\circ} \mathrm{C}$ which is roughly the average maximum summertime temperature in Portugal, when the insects activity is higher, and the tree is most probably releasing volatiles to fight back the attack. Similar SPME assay conditions were applied to the raw material after milling, in order to evaluate the effect of this required pre-extraction procedure on the raw material volatile composition, and consequently on the composition of the forthcoming extracts.

\subsubsection{Supercritical $\mathrm{CO}_{2}$ extraction}

Pine branches $\mathrm{scCO}_{2}$ extraction experiments were carried out in a laboratory-scale equipment (SFE $20 \mathrm{~mL}$ ) provided by Separex (Champigneulles, France) ${ }^{25}$. Raw material $\left(8.0 \times 10^{-3} \mathrm{~kg}\right)$ was placed in a $20 \times 10^{-6} \mathrm{~m}^{3}$ thermostatic stainless steel cell. The outlet $\mathrm{CO}_{2}$ flow rate, measured by a gas flow meter (Alexander Wright, UK), was set to $2.5 \mathrm{~L} / \mathrm{min}\left(\sim 7.5 \times 10^{-5} \mathrm{~kg} / \mathrm{s}\right)$ at ambient conditions. A solid-to-solvent ratio of 1:346 $\pm 13(\mathrm{w} / \mathrm{w}$, dry basis, d.b) was applied for all extractions, and total extraction time was set to $375 \mathrm{~min}(15 \mathrm{~min}$ of a static period followed by a $360 \mathrm{~min}$ dynamic period). Volatile oil extract fractions were collected in cooled flasks at pre-determined sampling times, and a glass wool packed column was used in order to prevent volatile losses with the exiting solvent stream. After depressurization, the tubing lines between the extraction cell and the collection flask were rinsed with ethanol after each extraction experiment. These ethanol-containing extract fractions (recovered during the extraction, and from final depressurization and line rising) were later evaporated (Rotovap R-210, Büchi). Glass wool packed columns were rinsed with ethyl acetate, which was then separated from the extracts in the fuming hood, under ventilation and at room temperature. Total yields were calculated as the ratio between the total extracted mass and the initial raw material mass, on a dry basis. The total mass of extract included the volatile fractions recovered in the collection flasks, from the final depressurization and line rinsing, and from the glass wool packed column. Before performing the analyses, the fractions recovered in the collection flasks were mixed with the ones from the depressurization and rinsing, and stored protected from light, at $-20^{\circ} \mathrm{C}$. 
Table 1

Experimental design with the coded values for $\mathrm{X}_{1}$ and $\mathrm{X}_{2}$.

\begin{tabular}{llll}
\hline Temperature $\left({ }^{\circ} \mathrm{C}\right)$ & Density $\left(\mathrm{kg} / \mathrm{m}^{3}\right)$ & $\mathrm{X}_{1}$ & $\mathrm{X}_{2}$ \\
\hline 35 & 600 & -1 & -1 \\
35 & 750 & -1 & 0 \\
35 & 900 & -1 & +1 \\
45 & 600 & 0 & -1 \\
45 & 750 & 0 & 0 \\
45 & 900 & 0 & +1 \\
55 & 600 & +1 & -1 \\
55 & 750 & +1 & 0 \\
55 & 900 & +1 & +1 \\
\hline
\end{tabular}

Extractions were performed in duplicate, in a randomized order, and $\mathrm{scCO}_{2}$ density $(600,750$ and $900 \mathrm{~kg} / \mathrm{m} \mathrm{[3])} \mathrm{and} \mathrm{temperature} \mathrm{(35,}$ 45 and $55^{\circ} \mathrm{C}$ ) were set up according to a $3^{2}$ full factorial design, resulting in operational pressures ranging from 84 bar up to 387 bar for the nine extraction conditions. Pressure values were calculated from the NIST (National Institute of Standards and Technology) data base. This experimental design was applied in order to evaluate the influence of these variables on total extraction yield and on extracts' properties (total phenolic contents, antioxidant activities and AChE inhibition activities).

A second-order response surface model was used:

$Y=\beta_{0}+\beta_{1} X_{1}+\beta_{2} X_{2}+\beta_{12} X_{1} X_{2}+\beta_{11} X_{1}^{2}+\beta_{22} X_{2}^{2}$

The coded variables were $X_{1}=\left(\frac{T-45}{45}\right)$, (where $\mathrm{T}$ is in ${ }^{\circ} \mathrm{C}$ ) and $X_{2}=\left(\frac{\rho-750}{750}\right)$, (where $\rho$ is in $\mathrm{kg} / \mathrm{m}^{3}$ ), Table $1 . \beta_{0}$ is the arithmetic mean response (intercept), $\beta_{1}$ and $\beta_{2}$ are the linear parameters of the corresponding variables $\left(\mathrm{X}_{1}, \mathrm{X}_{2}\right)$, and $\beta_{12}, \beta_{11}$, and $\beta_{22}$ are the quadratic parameters.

The response ( $Y$, dependent variable) corresponds to $\mathrm{Y}_{\mathrm{Y}}$ (total extraction yield, \%), $\mathrm{Y}_{\mathrm{TPC}}$ (total phenolic content, \% GAE), $\mathrm{Y}_{\mathrm{OI}}$ (oxidation inhibition, \%) or to $\mathrm{Y}_{\mathrm{AI}}$ (AChE inhibition activity, $\mathrm{IC}_{50}, \mathrm{mg} / \mathrm{mL}$ ), depending on the analysis. Only significant terms were kept in each response surface equation.

The agreement between the experimental data and the fitted model was evaluated using the coefficient of determination, $R^{2}$. The significance of regression coefficients was evaluated by $t$-tests and, therefore, the $t$-ratios and corresponding $p$-values were obtained. A $p$ value $<0.05$ (ideally $<0.0001$ ) was considered to be statistically significant and the obtained regression coefficients were used to generate surface plots. JMP $^{\circledR}$ software (Pro 13.1.0 version) was used to model and to analyze the results.

\subsubsection{Hydrodistillation}

HD experiments were performed using a Schilcher apparatus, at a solid-to-solvent ratio of 1:20 (w/w, d.b.) and during six hours, in triplicate. The volatile oil was recovered with dichloromethane, which was then evaporated at room temperature. The aqueous extract, resulting from the water in contact with the milled pine branches and obtained as a sub-product of this process, was separated from the exhausted raw material by vacuum filtration and subsequently freezedried. All dried extracts were stored at $-20^{\circ} \mathrm{C}$ and protected from light, until further analysis.

\subsection{Characterization of extracts}

\subsubsection{Volatile compounds analysis}

The naturally emitted volatiles from $P$. pinaster branches were identified by coupled gas chromatography mass spectrometry (GC/MS 7890A, 5975 C inert MSD with triple axis-detector, Agilent Technologies). The employed SPME fiber (PDMS/DVB) was immediately introduced in the injection port of the GC equipment after the adsorption procedure, and the trapped compounds were then desorbed at $250{ }^{\circ} \mathrm{C}$, for $1 \mathrm{~min}$. Separation was achieved on a DB5-MS fused silica capillary column $(30 \mathrm{~m} \times 0.25 \mathrm{~mm}$ i.d. $\times 0.25 \mu \mathrm{m}$, Agilent $\mathrm{J} \& \mathrm{~W}$ Scientific), using helium as the carrier gas, at a flow rate of $1 \mathrm{~mL} / \mathrm{min}$. The MS system was operated in the scan mode $(\mathrm{m} / \mathrm{z} 30-550 \mathrm{u})$ under an ionization potential of $70 \mathrm{eV}$, and a MS quadrupole temperature of $150{ }^{\circ} \mathrm{C}$. The temperature program included an isothermal $5 \mathrm{~min}$ period at $50^{\circ} \mathrm{C}$, followed by a temperature increase of $10^{\circ} \mathrm{C} / \mathrm{min}$ and up to $270^{\circ} \mathrm{C}$, where it was held for $5 \mathrm{~min}$ [26].

The volatile oils obtained by $\mathrm{scCO}_{2}$ extraction (corresponding to the fractions recovered in the collection flasks plus the ones from depressurization and tubing lines rinsing) and by HD were dissolved in ethyl acetate $(1 \mathrm{mg} / \mathrm{mL})$ and also analyzed by GC/MS with an injection volume of $0.2 \mu \mathrm{L}$. The volatiles trapped in the glass wool column were also identified by GC/MS. The temperature program was the same as the one described before.

The identification of volatile compounds was based on a comparison of their mass spectra with those of libraries (NIST and Flavors and Fragrances of Natural and Synthetic Compounds, FFNSC2.L).

The semi-quantitative analysis based on peak relative areas of the identified compounds was performed using a FID detector coupled to GC, using the same DB5 column, heating rate and equipment described before. All samples were analyzed in duplicate.

\subsubsection{Total phenolic contents}

Quantification of total phenolic compounds was done following the optimized Folin-Ciocalteu method developed by Cicco et al. [27]. Extracts were dissolved in methanol:water $(70: 30, \mathrm{v} / \mathrm{v}) ; 100 \mu \mathrm{L}$ of the extract or of the phenolic standard (gallic acid) were mixed with $100 \mu \mathrm{L}$ of the Folin-Ciocalteu reagent and, after $4 \mathrm{~min}$, with $800 \mu \mathrm{L}$ of an aqueous solution of $\mathrm{Na}_{2} \mathrm{CO}_{3}(5 \%)$. The mixture was kept at $40{ }^{\circ} \mathrm{C}$ for $20 \mathrm{~min}$, and the total phenolic content was determined colorimetrically at $750 \mathrm{~nm}$ (UV-vis spectrophotometer, Jasco, Model V650, Japan). Results (mean \pm standard deviation) were expressed as gallic acid equivalents (GAE), in percentage ( $\mathrm{mg} \mathrm{GAE} / \mathrm{mg}$ extract $\times 100$ ). Analyses were performed in triplicate.

\subsubsection{Antioxidant activity}

Antioxidant activity was assessed considering the possible future applications of the obtained extracts, such as in biocontrol formulations for plant pathogens, and recognizing that it is relevant to evaluate the extracts ability to prevent oxidative damage and eventually expand the life span of those formulations. The assay was based on the coupled oxidation of $\beta$-carotene and linolenic acid, already described [28]. Reactions were monitored at $470 \mathrm{~nm}$ by UV-vis absorbance readings during $3 \mathrm{~h}$, in triplicate. Antioxidant activities were expressed as oxidation inhibitions (\%). Two standard antioxidants, BHA and BHT, were used as references.

\subsubsection{AChE inhibitory activity assay}

The AChE inhibitory activity assay was performed (in triplicate) in order to evaluate the possible insecticidal/larvicidal potential of the extracts, following the procedure described by Ellman et al. [29] and modified by Ferreira et al. [30]. Extracts were previously dissolved in ethanol:Tris-HCl buffer (50:50, v/v). Briefly, $500 \mu \mathrm{L}$ of $3 \mathrm{mM}$ DTNB, $100 \mu \mathrm{L}$ of $15 \mathrm{mM}$ AChI, $275 \mu \mathrm{L}$ of $50 \mathrm{mM}$ Tris-HCl buffer at $\mathrm{pH} 8$, and $100 \mu \mathrm{L}$ of extract solution were added to a $1 \mathrm{~mL}$ cuvette, followed by $25 \mu \mathrm{L}$ of $0.28 \mathrm{U} / \mathrm{mL}$ AChE. The reaction was monitored for $5 \mathrm{~min}$ at $405 \mathrm{~nm}$, and the reaction rate was determined. Enzyme activity was calculated as a percentage of this velocity compared to that of the assay using buffer instead of inhibitor (extract). Inhibitory activity was then calculated by the subtraction of enzyme activity. For each extract, the procedure was repeated for, at least, three different extract concentrations and results were expressed as $\mathrm{IC}_{50}$ values. Two commercial insecticides, phosmet (Foslete ${ }^{\circledR}$ ) and dimethoate (Perfektion ${ }^{\circledR}$ ), were used as references. Both are organophosphates and inhibitors of the referred enzyme. 


\section{Results and discussion}

TGA analysis indicated a moisture content of the raw material (milled pine branches with a particle size smaller than $2 \mathrm{~mm}$ ) of $46.3 \pm 3.35 \%(\mathrm{w} / \mathrm{w})$. This value would probably be higher before freezing the samples, because some degree of drying may occur inside the freezing system. However, the aim of this analysis was the measurement of the water content in the raw material before extraction, to express results on a dry weight basis. As far as we know, there is no available thermogravimetric study for pine branches. However, since the collected samples were mainly composed of needles, this result is in agreement with previous findings by other authors that reported a moisture content close to $50 \%$ for fresh pine needles [31].

Raw material drying was not performed since air and oven drying, and even freeze-drying, typically show a limited ability to preserve bioactive compounds such as volatiles [32,33].

\subsection{Extraction yield of scCO2 extractions and $\mathrm{HD}$}

Total extraction yields obtained by $\mathrm{scCO}_{2}$ extraction ranged from $0.771 \%$ to $5.77 \%$, with higher yields being achieved for higher solvent density and temperature values (Table 2 and Fig. 1). These findings are in accordance with other studies of $\mathrm{scCO}_{2}$ extraction from plant aerial parts, namely the one of Gañán et al. [25], who reported higher extraction yields for $\mathrm{CO}_{2}$ densities above $700 \mathrm{~kg} / \mathrm{m}^{3}$ [34]. Other authors have also performed $\mathrm{scCO}_{2}$ extractions for $P$. pinaster wood chips at densities above $700 \mathrm{~kg} / \mathrm{m}^{3}$, and the obtained values were relatively high: $7.44 \%$ and $8.53 \%$, for conditions of $60^{\circ} \mathrm{C} / 200 \mathrm{bar}$ and $60^{\circ} \mathrm{C} /$ 300 bar, respectively [35].

In general, yield values obtained in this work for $P$. pinaster branches were higher than those obtained for $\mathrm{scCO}_{2}$ extracts of $P$. pinaster bark (0.97-1.37\%) [36]] and P. nigra needles (1.60\%) [37]. These differences may be explained by the fact that these extractions were performed using different pine tree tissues (branches include needles, wood and bark), different pine species with diverse geographical origins and different extraction conditions. However, the water present in the pine branches used in this work (that were not previously dried to preserve volatile compounds) may have contributed to increase overall extraction yields, by playing the role of a co-solvent and increasing the overall solvent polarity and, consequently, the nature of the compounds being extracted [32]. The volatile oil total extraction yield obtained by $\mathrm{HD}(0.160 \pm 0.030 \%)$ was lower than those of $\mathrm{scCO}_{2}$ extraction experiments, which is in accordance with previous works that focused on $P$. pinaster extractions [38], and also with several others that focused on aerial parts of other plants. For Tanacetum parthenium L., HD yield was $\sim 0.5 \%$ while for $\mathrm{scCO}_{2}$ extractions it was $2.5-3.75 \%$ [39]. The same

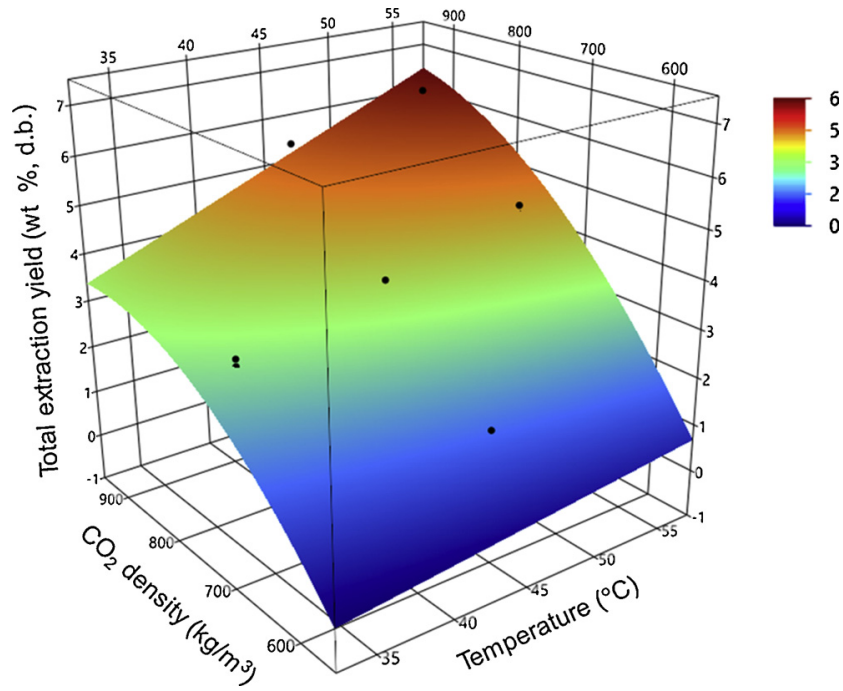

Fig. 1. 3D response surface plot for the influence of solvent density $\left(\mathrm{kg} / \mathrm{m}^{3}\right)$ and temperature $\left({ }^{\circ} \mathrm{C}\right)$ on total extraction yield.

trend was observed for Salvia mirzayanii [40] and Echinophora platyloba [41].

On the other side, HD aqueous extract yield was $19.7 \pm 2.1 \%$, revealing that pine branches have plenty of aqueous soluble compounds.

The quadratic model that fits $\mathrm{scCO}_{2}$ total extraction yield $\left(\mathrm{Y}_{\mathrm{Y}}\right)$ is represented by Equation 2, and the corresponding response surface is plotted in Fig. 1.

$Y_{Y}=3.62+0.78 X_{1}+1.74 X_{2}+0.35 X_{1} X_{2}-0.58 X_{2}^{2}$

$\left(R^{2}=0.96\right)$

Predicted values of total extraction yield are clearly in agreement with experimental results, as denoted by the $R^{2}$ value. There is a positive effect of solvent density on yield, as confirmed by the significant and positive linear density parameter (1.74) and by the correspondent high $t$-ratio value (Table 3 ), being related with a higher solvent capacity due to stronger interactions between the fluid and the vegetable matrix (the $\mathrm{X}_{2}^{2}$ parameter, despite being negative, has lower significance ( $p$ value of 0.0149)). Moreover, an increment in temperature also resulted in higher yields (Fig. 1), which is confirmed by the positive and significant linear temperature parameter $\left(\mathrm{X}_{1}\right), 0.78$. This trend of yield increase with temperature at a constant solvent density is widely reported in literature, being associated with the higher solutes vapor pressures and subsequently higher solubilities in the supercritical fluid,

Table 2

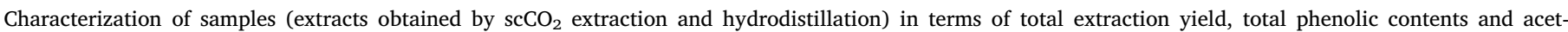
ylcholinesterase inhibition activity, which was also evaluated for organophosphorus commercial insecticides.

\begin{tabular}{|c|c|c|c|c|c|c|c|}
\hline \multirow[t]{2}{*}{ Samples } & \multicolumn{4}{|l|}{ Process conditions } & \multirow{2}{*}{$\begin{array}{l}\text { Total extraction yield } \\
\text { (wt \%, d.b.) }\end{array}$} & \multirow{2}{*}{$\begin{array}{l}\text { Total phenolic content } \\
\text { (GAE, \%) }\end{array}$} & \multirow{2}{*}{$\begin{array}{l}\text { AChE inhibition } \\
\text { activity } \\
\left(\mathrm{IC}_{50}, \mathrm{mg} / \mathrm{mL}\right)\end{array}$} \\
\hline & Condition number & $\mathrm{T}\left({ }^{\circ} \mathrm{C}\right)$ & $\mathrm{P}$ (bar) & $\rho_{\mathrm{CO} 2}\left(\mathrm{~kg} / \mathrm{m}^{3}\right)$ & & & \\
\hline \multirow[t]{9}{*}{$\mathrm{scCO}_{2}$ extracts } & 1 & 35 & 84 & 600 & $0.771 \pm 0.038$ & $3.25 \pm 0.065$ & $5.30 \pm 0.55\left(R^{2}=0.99\right)$ \\
\hline & 2 & 45 & 110 & & $1.49 \pm 0.41$ & $2.08 \pm 0.13$ & $2.83 \pm 0.016\left(\mathrm{R}^{2}=0.90\right)$ \\
\hline & 3 & 55 & 136 & & $1.65 \pm 0.012$ & $2.67 \pm 0.27$ & $3.60 \pm 0.31\left(R^{2}=0.98\right)$ \\
\hline & 4 & 35 & 112 & 750 & $2.93 \pm 0.11$ & $2.72 \pm 0.080$ & $6.33 \pm 0.47\left(\mathrm{R}^{2}=0.98\right)$ \\
\hline & 5 & 45 & 154 & & $3.49 \pm 0.33$ & $1.44 \pm 0.12$ & $3.46 \pm 0.21\left(\mathrm{R}^{2}=1.00\right)$ \\
\hline & 6 & 55 & 197 & & $4.44 \pm 0.13$ & $1.56 \pm 0.10$ & $7.81 \pm 0.18\left(\mathrm{R}^{2}=0.98\right)$ \\
\hline & 7 & 35 & 248 & 900 & $3.51 \pm 0.078$ & $1.58 \pm 0.11$ & $5.83 \pm 0.075\left(\mathrm{R}^{2}=1.00\right)$ \\
\hline & 8 & 45 & 317 & & $5.08 \pm 0.91$ & $1.51 \pm 0.088$ & $10.7 \pm 0.36\left(\mathrm{R}^{2}=0.98\right)$ \\
\hline & 9 & 55 & 387 & & $5.77 \pm 0.74$ & $1.23 \pm 0.083$ & $3.99 \pm 0.52\left(R^{2}=0.99\right)$ \\
\hline \multirow[t]{2}{*}{ HD extracts } & \multicolumn{4}{|l|}{ Volatile oil $\left(100^{\circ} \mathrm{C}\right)$} & $0.160 \pm 0.030$ & $1.11 \pm 0.064$ & $3.98 \pm 0.13\left(R^{2}=0.93\right)$ \\
\hline & \multicolumn{4}{|c|}{ Aqueous extract $\left(100^{\circ} \mathrm{C}\right)$} & $19.7 \pm 2.1$ & $2.41 \pm 0.20$ & $9.19 \pm 0.42\left(\mathrm{R}^{2}=0.97\right)$ \\
\hline \multirow[t]{2}{*}{ Organophosphorus insecticides } & \multicolumn{4}{|c|}{ Phosmet (Foslete $\left.{ }^{\circledast}\right)$} & - & - & $13.9 \pm 1.1\left(\mathrm{R}^{2}=0.99\right)$ \\
\hline & \multicolumn{4}{|c|}{ Dimethoate (Perfekthion ${ }^{\circledast}$ ) } & - & - & $12.6 \pm 0.10\left(\mathrm{R}^{2}=0.99\right)$ \\
\hline
\end{tabular}

$\mathrm{T}=$ temperature; $\mathrm{P}=$ pressure; $\rho=$ density. 
Table 3

Statistical results for the factorial design applied to evaluate the influence of temperature and $\mathrm{CO}_{2}$ density on extraction yield and extract properties.

\begin{tabular}{|c|c|c|c|c|c|c|}
\hline \multirow[t]{3}{*}{ Parameter } & \multicolumn{6}{|c|}{ Response } \\
\hline & \multicolumn{2}{|c|}{$\begin{array}{l}\text { Total extraction yield } \\
\left(\mathrm{Y}_{\mathrm{Y}}\right)\end{array}$} & \multicolumn{2}{|c|}{$\begin{array}{l}\text { Total phenolic } \\
\text { contents }\left(\mathrm{Y}_{\mathrm{TPC}}\right)\end{array}$} & \multicolumn{2}{|c|}{$\begin{array}{l}\text { AChE inhibition } \\
\text { activity }\left(\mathrm{Y}_{\mathrm{AI}}\right)\end{array}$} \\
\hline & $t$-ratio & $p$-value & $t$-ratio & $p$-value & $t$-ratio & $p$-value \\
\hline $\mathrm{X}_{1}$ & 6.70 & $\begin{array}{l}< \\
0.0001\end{array}$ & -5.00 & $<0.0001$ & n.s. & n.s. \\
\hline$X_{2}$ & 15.03 & $\begin{array}{l}< \\
0.0001\end{array}$ & -8.78 & $<0.0001$ & 2.90 & 0.00076 \\
\hline $\mathrm{X}_{1}^{2}$ & n.s. & n.s. & 4.05 & 0.0005 & n.s. & n.s. \\
\hline$X_{1} X_{2}$ & 2.45 & 0.013 & n.s. & n.s. & n.s. & n.s. \\
\hline $\mathrm{X}_{\mathbf{2}}^{2}$ & -2.87 & 0.0149 & n.s. & n.s. & n.s. & n.s. \\
\hline
\end{tabular}

n.s. $=$ non-significant $(p>0.05)$.

along with higher diffusion coefficients that favor mass transfer through the matrix [42]. This increment of extraction yield with temperature is especially noticed for high $\mathrm{CO}_{2}$ density values, and therefore a synergistic effect between temperature and solvent density exists, as denoted by the positive interaction parameter $\left(\mathrm{X}_{1} \mathrm{X}_{2}\right)$, although with lower statistical impact (Table 3).

Fig. 2 represents the relative amounts of recovered extracts: 1) from the collection flask after the 375-min extraction, 2) from system depressurization and tubing lines rising, and 3) from the glass wool packed column. As can be observed, the relative amount of extract that was retained in the exit line (between the extraction cell and the collection flask) represented $25 \%-77 \%$ of the total amount of obtained extract. This relative amount seem to decrease with temperature (at constant solvent density) and with density (at constant temperature). Since the relative amount of extract recovered from the packed column was approximately the same for all tested extraction conditions (4-9\%), the amount that ended up in the collection flask showed an opposite trend. The deposition of extracted compounds within outlet tubing lines from $\mathrm{CO}_{2}$ extraction cells is a quite common situation, being a consequence of the depressurization that occurs in the tubing line, combined with the Joule-Thomson cooling effect of the expanding $\mathrm{CO}_{2}$ at the tubing line exit. Both these phenomena contribute to a decrease in the extracted compounds solubility, with consequent formation of clusters, often combined with particles of solid $\mathrm{CO}_{2}$, that reduce substances diffusion coefficients and particles mobility [43]. For higher density and temperature values, it seems that the solubility and mobility of the extracted compounds within the exiting tubing line was less impaired.

Fig. S1 (Supporting Information) represents the extraction curves obtained in this work for pine branches $\mathrm{scCO}_{2}$ extractions. The retention of extract within the exit line and the formation of clusters may have altered some extraction profiles, especially for the lowest

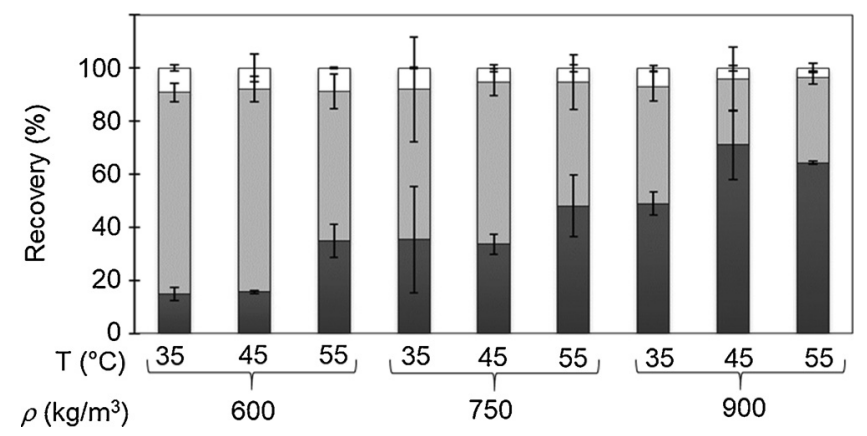

Fig. 2. Extract fractions (\%) recovered during the 375-min extraction ( $\square$ ), from the final depressurization and tubing lines rinsing ( $\boldsymbol{\square})$, and from the glass wool packed column ( $\square$ ). temperature and density conditions, and therefore extraction curves were probably affected by those events.

\subsection{Characterization of extracts}

\subsubsection{Volatile compounds analysis}

Table S1 (Supporting Information) reports the chemical composition of volatiles naturally emitted from $P$. pinaster branches, as well as those present in $\mathrm{HD}$ and $\mathrm{scCO}_{2}$ extracts. Fig. 3 shows the corresponding GC/MS chromatograms. Abbreviated information containing the subtotal percentages of the main categories of compounds is included in Table 4.

Twenty three compounds were identified in the volatiles naturally emitted by the pine branches, accounting for $\sim 58 \%$ of the total peaks area. Most of these volatile compounds correspond to monoterpenes (43.4\% of the total peak area) and sesquiterpene hydrocarbons $(13.8 \%)$, with retention times in the $7-26 \mathrm{~min}$ range. The main identified components were $\alpha$-pinene, $\beta$-pinene (these two isomers accounted for $\sim 20 \%$ of the total peak area), along with $\beta$-myrcene, limonene and $\beta$-caryophyllene, being in accordance with compounds already found by other authors for $P$. pinaster needles, branches and bark $[2,11]$. Special attention should be given to $\beta$-caryophyllene that is known to be repellent to the pine shoot beetle, Tomicus destruens [44].

Branches collection was performed during summertime, when insects' activity is known to be higher. Hence, this blend of volatiles may possibly mimic the volatiles naturally emitted by $P$. pinaster trees during the period when these compounds play an important role in mediating the behavior of their natural enemies, and in triggering plant-plant communication to prevent further attacks [45,46]. The diterpene abietadiene was also identified among the volatiles naturally emitted by pine branches, despite at a relative low concentration of $0.579 \%$. This compound is the precursor of abietic acid, which has activity against insects [5].

Considering the volatile compounds identified in the $\mathrm{scCO}_{2}$ and $\mathrm{HD}$ extracts, it should be noted that the milling step carried out before these extractions did not change the compounds naturally emitted by the branches. Results from the SPME assay performed with the milled pine branches are included in Fig. S2 (Supporting Information). Volatile compounds similar to those obtained for intact branches fragments were identified, including $\alpha$-pinene and $\beta$-pinene, $\beta$-myrcene, limonene and $\beta$-caryophyllene, among others.

Around 30-40 compounds were identified in the $\mathrm{scCO}_{2}$ extracts, depending on the extraction conditions, and accounting for $\sim 55-74 \%$ of the total peaks area. Some of these volatiles are typically identified in pine samples, including monoterpenes like $\alpha$-pinene, $\beta$-pinene, $\beta$-myrcene and limonene, and sesquiterpene hydrocarbons $(3.28-12.8 \%$ of the total peaks area) such as $\alpha$-cubebene, $\beta$-caryophyllene, $\alpha$-caryophyllene, $\gamma$-cadinene, $\beta$-copaene, $\Delta$-cadinene, and $\alpha$-cadinene, among others. However, these low-molecular weight compounds were found in lower amounts when compared to the naturally emitted volatiles. Some of these compounds were probably dragged out with the exiting gaseous $\mathrm{CO}_{2}$ stream (despite the presence of the glass wool column to trap the volatiles). Most of the volatile compounds that were identified in the $\mathrm{scCO}_{2}$ extracts had higher molecular weights and thus higher retention times (Tables 4 and S1, Fig. 3). They corresponded essentially to diterpene hydrocarbons (29.6-43.7\%) and to oxygenated diterpenes (9.79-29.7\%). Abietadiene, naturally emitted by pine branches at low relative percentages (as detected by SPME), was the main volatile for all extraction conditions (25.1-36.3\%). Despite the well-known tendency of volatile compounds solubility to increase with temperature and $\mathrm{scCO}_{2}$ density (associated with a rise in vapor pressure and solventsolute interactions, respectively) [33], abietadiene was relatively more abundant in the extracts obtained at both lower temperature and lower solvent density (Fig. 4). These were the experimental conditions that conducted to lower extraction yields (as previously discussed), and thus abietadiene was present in relatively higher amounts in these extracts. 


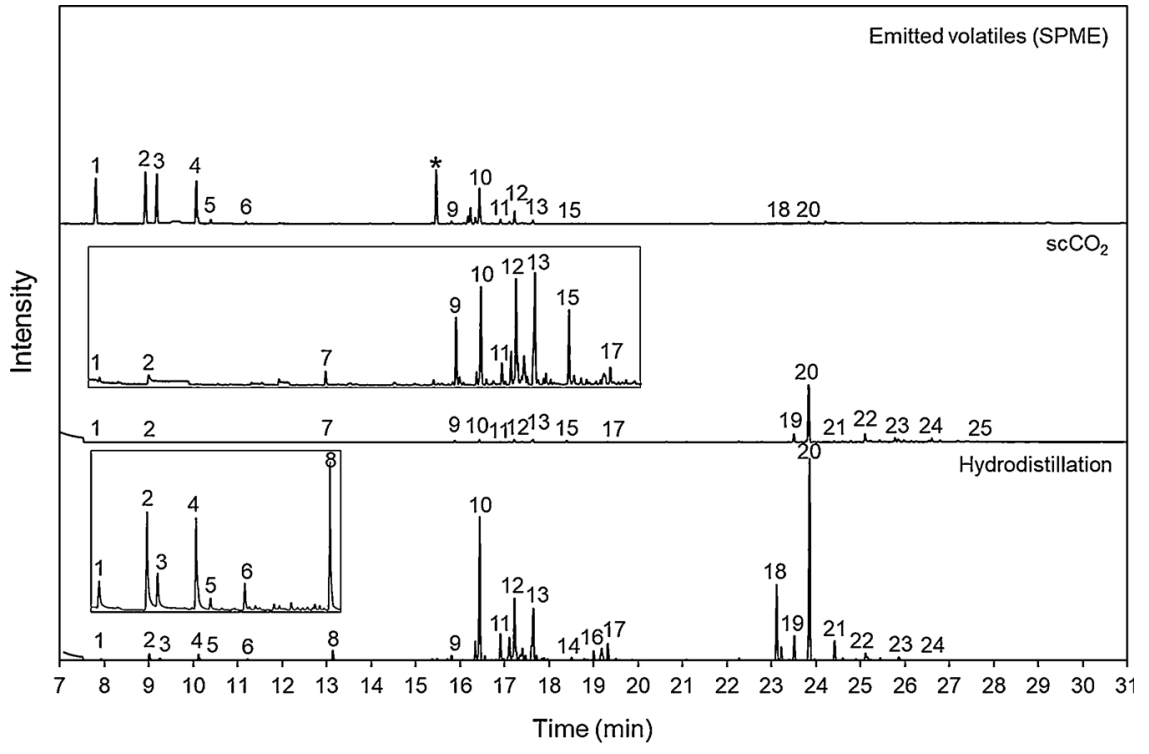

Fig. 3. Volatile compounds naturally emitted from $P$. pinaster branches (SPME) and present in $\mathrm{HD}$ and $\mathrm{scCO}_{2}$ extracts $\left(35{ }^{\circ} \mathrm{C}\right.$ and $\left.750 \mathrm{~kg} / \mathrm{m}^{3}\right)$. Peak identification: 1. $\alpha$ pinene; 2. $\beta$-pinene; 3. $\beta$-myrcene; 4. limonene; 5 . $\beta$-ocimene; 6. terpinolene; 7. dodecylacetate; 8. $\alpha$-terpineol; 9. $\beta$-cubebene; 10. $\beta$-caryophyllene; 11. $\alpha$-caryophyllene; 12. $\beta$-copaene; 13. $\Delta$-cadinene; 14. caryolan-8-ol; 15. (-)-caryophyllene oxide; 16. $\tau$-muurolol; 17 . cadin-4-en-10-ol; 18. rimuene; 19 . dehydroabietane; 20 . abietadiene; 21. abieta-(8(14), 13(15)-diene); 22. manool or labda8(17).13z-dien-15-ol; 23. abietal; 24. abietol; 25. abietic acid; * peak attributed to the fiber.
This compound is the precursor of abietic acid, which is produced by conifer species as a defensive secretion against insect and pathogen attacks [5].

In the $\mathrm{scCO}_{2}$ extracts obtained in this work, abietic acid eluted in relatively low quantities (0.504-4.12\%), at $27.21 \mathrm{~min}$ (Fig. 3], Table S1). These findings are in accordance with the literature, since abietadiene was already identified in volatile oils of $P$. pinaster wood, cones and needles [47], and in Euonymus europaeus seed extracts and Juniperus procera berries extracts, which revealed insecticidal [48] and antiparasitic activities [49], respectively. Abietic acid was found in the oleoresin of $P$. sylvestris wood [50]], and in Abies balsamea L. Mill. extracts [51]. Seven additional compounds structurally related with abietic acid and abietadiene were identified in considerable amounts in the $\mathrm{scCO}_{2}$ extracts: dehydroabietane, abieta-(8(14),13(15)-diene), abietal, abietol, dehydroabietol, dehydroabietic acid, and neo-abietol. They were already reported in the literature in extracts from $P$. sylvestris [52], P. sibirica [53], Picea schrenkiana Fisch [54]], Abies balsamea L. Mill. [51], and Vitex Trifolia [55], and some of them revealed potential medicinal applications.

Similar compounds to those identified in the $\mathrm{scCO}_{2}$ extracts were also eluted in the GC/MS from the correspondent glass wool packed columns, which confirms the ability of the equipment to retain the main volatile compounds within the collection flask.

In the HD volatile oil, fifty-three compounds were identified, accounting for $\sim 93 \%$ of the total peaks area. Volatiles naturally emitted by pine trees were also present, corresponding to those also identified by SPME (Fig. 3). Monoterpene hydrocarbons and oxygenated diterpenes accounted for approximately $4 \%$ and $3 \%$ of the total peaks area, respectively. Particularly, $\beta$-caryophyllene, $\beta$-copaene, $\Delta$-cadinene, and rimuene were present in substantial amounts, above $7 \%$ (Fig. 3, Table S1). Sesquiterpene hydrocarbons (44.7\%) and diterpene hydrocarbons $(34.6 \%)$ were present at high relative percentage areas and, as happened for the $\mathrm{scCO}_{2}$ extracts, abietadiene was the most abundant compound (20.5\%). Compounds structurally related with abietadiene were also identified. These findings are in agreement with the results obtained by other authors for $P$. pinaster wood extracts obtained by steam distillation, and mainly composed by terpenes $[35,47]$.

\subsubsection{Total phenolic contents}

The $\mathrm{scCO}_{2}$ extracts total phenolic contents varied in the range 1.2-3.3 \% GAE (Table 2). These values are in agreement with the ones obtained by other authors for $P$. pinaster wood $\mathrm{scCO}_{2}$ extracts, that were up to $2.1 \%$ GAE [56]. These relatively low phenolic contents may be attributed to the fact that high molecular mass phenolic compounds that are known to compose pine tree tissues, such as stilbenes and flavonoids, are hardly soluble in pure $\mathrm{CO}_{2}$ [32]. Therefore, the addition of a co-solvent such as ethanol may possibly be used, if the extraction of such compounds is envisaged [36 [56,57].

Eq. (3) represents the model that fits $\mathrm{scCO}_{2}$ extracts total phenolic contents $\left(\mathrm{Y}_{\mathrm{TPC}}\right)$. The corresponding response surface is plotted in Fig. 5.

$Y_{T P C}=1.68-0.35 X_{1}-0.61 X_{2}+0.49 X_{1}^{2}$

$\left(\mathrm{R}^{2}=0.84\right)$

As indicated by the $R^{2}$ value, predicted values are in reasonable agreement with experimental data. Both $\mathrm{CO}_{2}$ density and extraction temperature had significant and negative effects on extracts total phenolic contents, as confirmed by the negative linear parameters and corresponding $p$-values (Table 3 ). However, for the quadratic parameter $\mathrm{X}_{1}^{2}$, a positive effect was observed, though with slightly lower statistical significance. Considering the positive effect that both variables had on extraction yield, low $\mathrm{CO}_{2}$ densities and temperatures seem to be more selective for phenolic compounds. The lower amount of phenolic compounds at higher temperatures can be ascribed to partial thermal degradation of these compounds, as already described by other authors [14]. The interaction parameter between the two variables $\left(\mathrm{X}_{1} \mathrm{X}_{2}\right)$, as well as the one of the quadratic parameter $\mathrm{X}_{1}{ }^{2}$ were not significant.

Total phenolic contents in the HD extracts were $\sim 1.1 \%$ and $\sim 2.4 \%$ of GAE for the volatile oil and aqueous extract, respectively (Table 2).

\subsubsection{Antioxidant activity}

Antioxidant activity of $\mathrm{scCO}_{2}$ extracts, expressed by their oxidation inhibition in the $\beta$-carotene/linolenic acid system, is represented in Fig. 6. In general, extracts revealed oxidation inhibitions in the range $42-59 \%, 3 \mathrm{~h}$ after the beginning of the assay, with a slight decrease between 1 and $3 \mathrm{~h}$. Since all values were close to $50 \%$, independently of the extraction conditions, no correlation with extraction temperature and solvent density could be observed, as confirmed by the non-significant parameters obtained (not shown). Therefore, no model for the response variable $\mathrm{Y}_{\mathrm{OI}}$ was able to fit this set of experimental data. Oxidation inhibition values between $29 \%$ and $62 \%$ were observed by other authors for $P$. pinaster bark $\mathrm{scCO}_{2}$ extracts [38].

Other $P$. pinaster bark extracts, rich in procyanidins, have also revealed antioxidant activity [58]. No direct correlation between total phenolic contents and antioxidant activity of $\mathrm{scCO}_{2}$ extracts was observed, since extracts presented rather similar oxidation inhibition values, independently of their phenolic contents (Fig. 7A). Other authors 


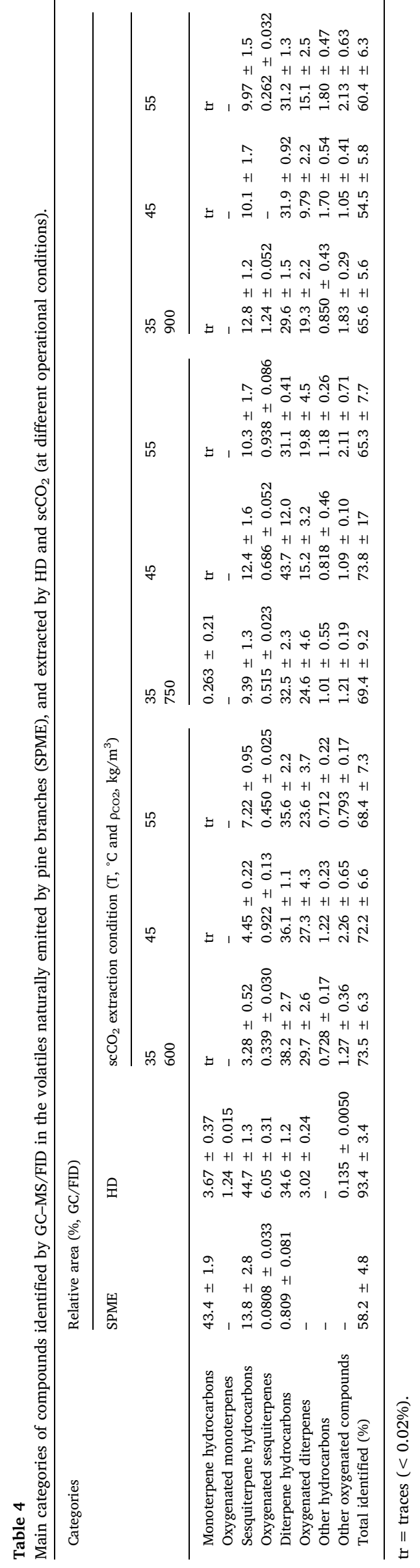

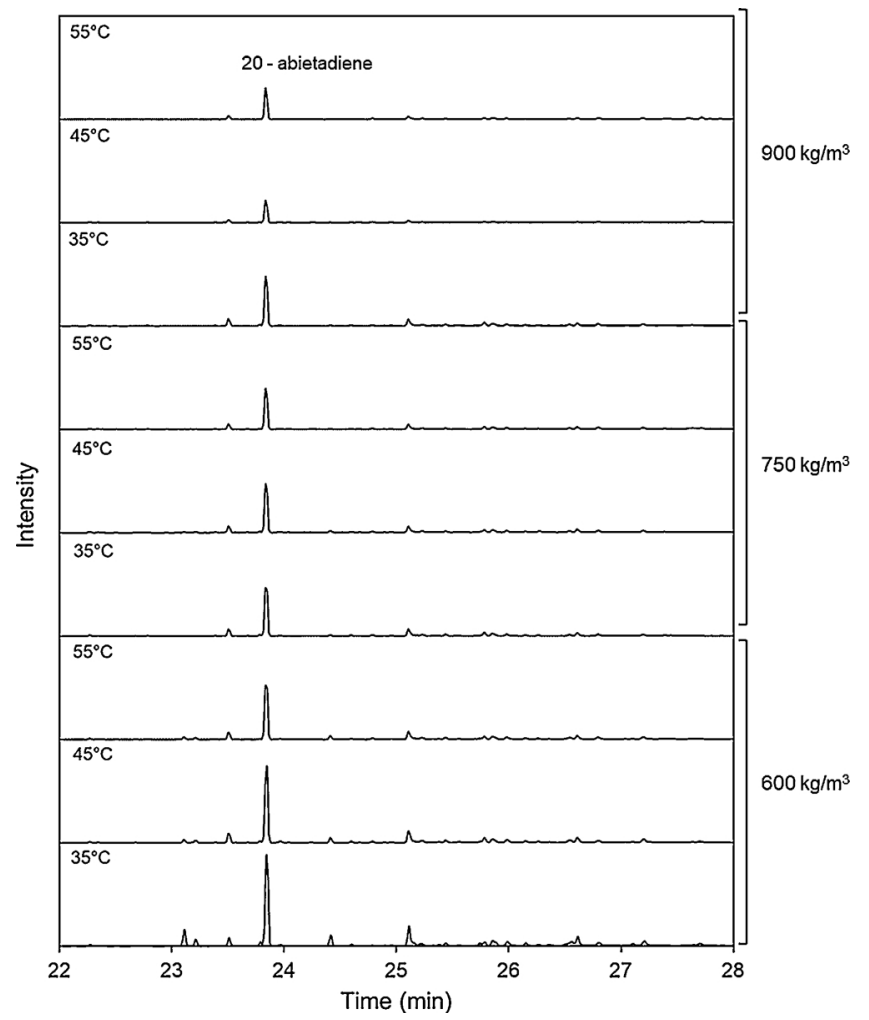

Fig. 4. Detail of the GC/MS chromatograms $(22-28 \mathrm{~min})$ of the extracts obtained by $\mathrm{scCO}_{2}$ extraction at different solvent densities $(600,750$, and $900 \mathrm{~kg} /$ $\mathrm{m}^{3}$ ) and temperatures $\left(35,45\right.$, and $\left.55^{\circ} \mathrm{C}\right)$. Abietadiene is identified by the number 20 (similarly to Fig. 3).

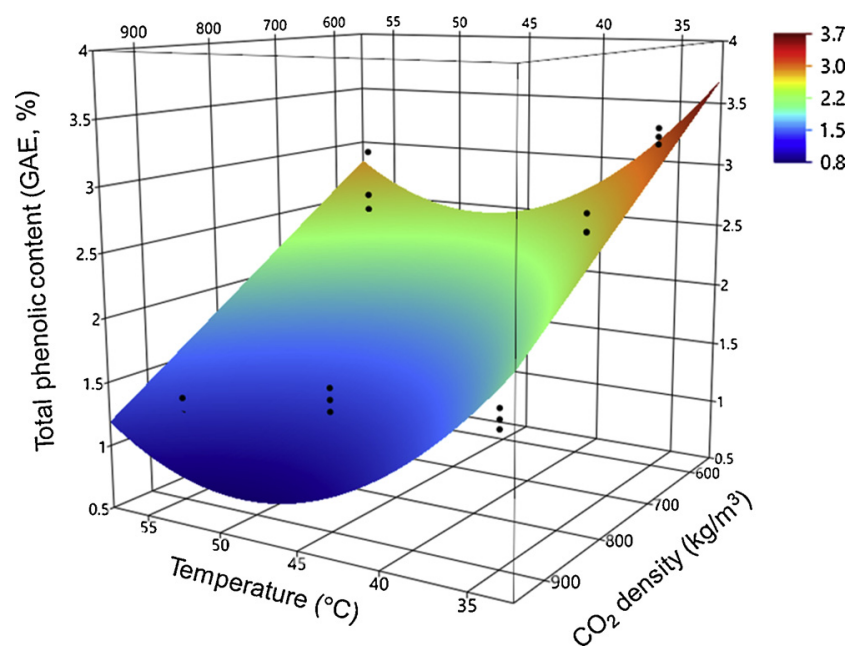

Fig. 5. 3D response surface plot for the influence of solvent density $\left(\mathrm{kg} / \mathrm{m}^{3}\right)$ and temperature $\left({ }^{\circ} \mathrm{C}\right)$ on total phenolic content (GAE, \%).

have also observed the lack of significant correlations between these two variables when studying pine and other plant materials [36]. The explanation may be related to the fact that extracts' antioxidant activity depends on the presence of specific compounds, such as terpenoids and carotenoids that were not quantified, and not only on the presence of phenolic compounds [32,59].

Despite having phenolic contents of the same order of magnitude of the $\mathrm{scCO}_{2}$ extracts, the $\mathrm{HD}$ volatile oil was able to enhance $\beta$-carotene oxidation, i.e. it apparently had a pro-oxidant activity, instead of inhibiting the oxidation. Similarly, the HD aqueous extract revealed a pro-oxidant activity that turned into a low antioxidant activity towards 

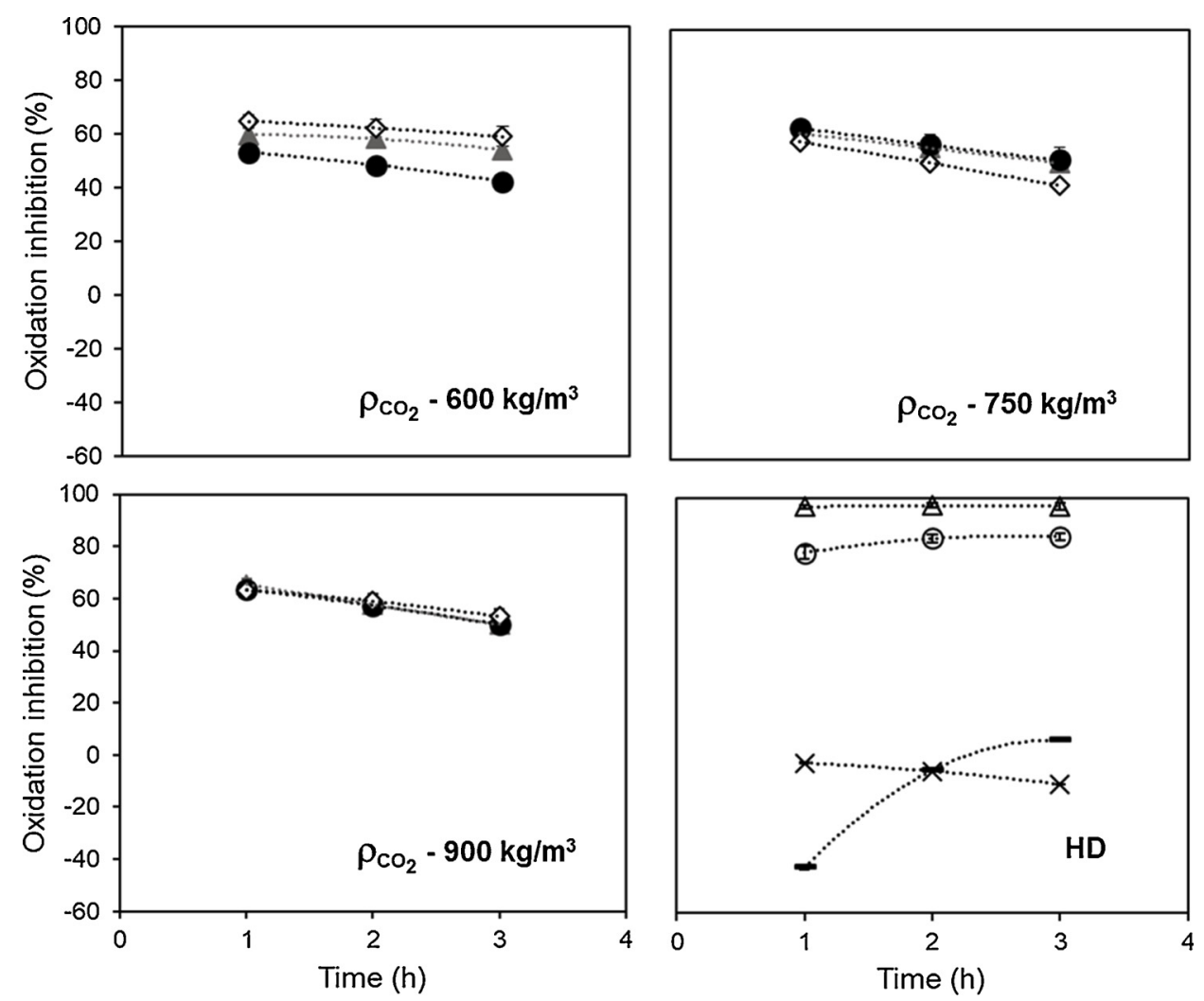

Fig. 6. Oxidation inhibition (\%) for extracts obtained by $\mathrm{scCO}_{2}$ extraction at different densities, and at different conditions of temperature: $35^{\circ} \mathrm{C}(\mathbf{\Delta}), 45^{\circ} \mathrm{C}(\bullet), 55^{\circ} \mathrm{C}(\diamond)$. The oxidation inhibition for extracts obtained by HD: volatile oil $(x)$ and aqueous extract $(-)$; and for two reference compounds, BHA $(\Delta)$ and BHT (O), are also represented.
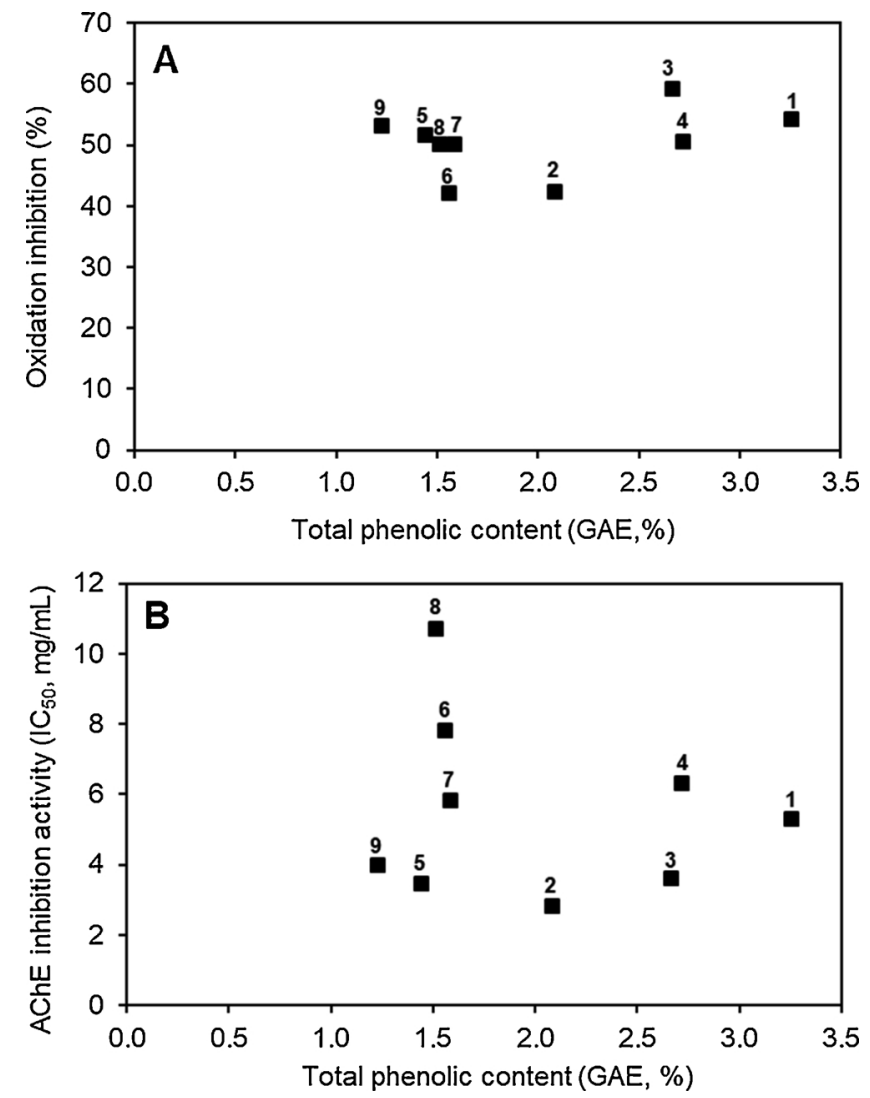

Fig. 7. Correlation of results from antioxidant activity with total phenolic content (A); and AChE inhibition activity $\left(\mathrm{IC}_{50}, \mathrm{mg} / \mathrm{mL}\right.$ ) with total phenolic content (B), for all the extracts obtained by $\mathrm{scCO}_{2}$ extraction (Conditions 1-9, see Table 2). the end of the assay (Fig. 6). These results also confirm that antioxidant activity and phenolic contents may not correlate, and corroborates the hypothesis that $\mathrm{scCO}_{2}$ extracts probably had other compounds that were not quantified but were responsible for the high antioxidant activity.

During extraction of essential oils by hydrodistillation, extracted components are exposed to heat, light and oxygen, which may trigger loss of antioxidant activity. Oppositely, a $\mathrm{scCO}_{2}$ extraction system protects extracted components from light, oxygen, and excessive heat, and therefore minimizes possible degradation reactions. Results of this work have demonstrated that the $\mathrm{scCO}_{2}$ extraction method is more effective than HD method in achieving extracts with higher antioxidant activity from $P$. pinaster branches.

\subsubsection{AChE inhibitory activity}

The ability of the pine branches extracts to inhibit the activity of AChE was analysed, and results were expressed as $\mathrm{IC}_{50}$ values. This enzyme catalyzes the hydrolysis of the neurotransmitter acetylcholine into choline and acetic acid $[30,60]$, a reaction needed to terminate the neuronal excitement at the postsynaptic membrane in insects. Commercial organophosphorus insecticides act by irreversibly inhibiting AChE, leading to acetylcholine accumulation and excessive neuro excitation. The symptoms include hyperexcitability, tremors, convulsions and paralysis, eventually leading to death $[16,61]$.

The concentration ranges used in the AChE assay were adapted to the inhibition revealed by each sample, so that the calculation of the $\mathrm{IC}_{50}$ value would be possible. Therefore, for phosmet, the concentration range was $1.1-30.2 \mathrm{mg} / \mathrm{mL}$, while for dimethoate, it was $7.6-20.3 \mathrm{mg}$ / $\mathrm{mL}$. For HD, the concentrations were $3.3-5.3 \mathrm{mg} / \mathrm{mL}$ (volatile oil) and $4.3-12.4 \mathrm{mg} / \mathrm{mL}$ (aqueous extract), and for $\mathrm{scCO}_{2}$ extracts the range was dependent on the extraction conditions, as follows: condition number 1 (1.3-8.5 mg/mL); $2(1.1-4.2 \mathrm{mg} / \mathrm{mL}) ; 3(1.3-5.2 \mathrm{mg} / \mathrm{mL}) ; 4$ (3.5-9.6 mg/mL); $5 \quad(1.6-6.4 \mathrm{mg} / \mathrm{mL}) ; \quad 6 \quad(3.1-9.2 \mathrm{mg} / \mathrm{mL}) ; \quad 7$ (2.3-9.2 mg/mL); 8 (6.0-14.3 mg/mL); and $9(1.2-4.7 \mathrm{mg} / \mathrm{mL})$.

For the $\mathrm{scCO}_{2}$ extracts, $\mathrm{IC}_{50}$ values were in the $2.83-10.7 \mathrm{mg} / \mathrm{mL}$ 
range, with $\mathrm{R}^{2}$ values being in most cases very close to 1.00 , indicating a linear correlation (Table 2 and Fig. S3). The two commercial organophosphates used as standards in this assay, phosmet and dimethoate, showed $\mathrm{IC}_{50}$ values of $13.9 \pm 1.1 \mathrm{mg} / \mathrm{mL}$ and $12.6 \pm 0.10 \mathrm{mg} / \mathrm{mL}$, respectively. The obtained $\mathrm{IC}_{50}$ values of the pine branches $\mathrm{scCO}_{2}$ extracts revealed their possible action as insecticides/larvicides. Despite the lower IC $_{50}$ values showed by the extracts when compared to the commercial organophosphates, it should be taken into account that both used standards are pro-insecticides that require oxidative desulfuration for the corresponding oxon to be active [15]. Therefore, the $\mathrm{IC}_{50}$ values obtained in vitro for the standards may be lower in vivo. Other standards, such as malathion or malaoxon, do not require bioactivation in vivo. Nevertheless, in this study, the aim was to compare the AChE inhibition revealed by the extracts with currently used and authorized insecticides in the Portuguese agro-forestry, such as phosmet and dimethoate.

Only a few authors have studied the insecticidal potential of plantbased products using this technique. Some of them have focused on the role of different chemical classes of compounds, and found out that tannins [62], alkaloids [63], phenolic compounds [22], as well as monoterpenoids [64,65] and one diterpene (gossypol) [46] were active against AChE or showed avoidance behavior/ insecticidal activity. In particular, Maazoun and co-workers [22] obtained an IC 50 value of $66 \mu \mathrm{g} / \mathrm{mL}$ for a conventional methanolic extract of Urginea maritima fresh bulbs, rich in phenolic compounds. Other authors have used the AChE inhibitory activity assay to evaluate the larvicidal activity of $P$. densiflora needles hydrodistillate. They analyzed the individual activity of some volatiles present in the extract, and found high larvicidal activity for thymol and $\delta$-3-carene, with IC $_{50}$ below $2 \mathrm{mM} \mathrm{[61].} \mathrm{Similarly,}$ Perumalsamy et al. [20] evaluated the insecticidal activity of flavonoids and fatty acids from Millettia pinnata seeds, by analyzing the inhibition of AChE extracted from insect larvae. The compounds karanjachromene, pongarotene, pongamol, and oleic acid showed the most potent inhibitory activity ( $\mathrm{IC}_{50}, 3.3-5.9 \mathrm{mM}$ ). Finally, Hematpoor and colleagues [66] have evaluated the insecticidal activity of phenylpropanoids isolated from extracts of Piper sarmentosum Roxb roots, and observed the highest AChE inhibitory activity for asaricin and isoasarone. Insecticidal activity was also found for one sesquiterpene obtained from Alpinia oxyphylla [67].

Eq. 4 represents the simplified model obtained for the AChE inhibitory activity in terms of $\mathrm{IC}_{50}$.

$Y_{A I}=5.53+1.46 X_{2}$

\section{$\left(R^{2}=0.25\right)$}

Despite the low $R^{2}$ value, the $\mathrm{CO}_{2}$ density parameter had a significant and positive effect on IC $_{50}$ values, as confirmed by the positive linear parameter and corresponding $p$-value (Table 3 ). This means that lower solvent densities appear to favor low IC 50 values, specifically at a temperature of $45^{\circ} \mathrm{C}$ (Fig. 8). In fact, the three extracts with the lowest $\mathrm{IC}_{50}$ values were obtained at lower $\mathrm{CO}_{2}$ densities $\left(600\right.$ and $\left.750 \mathrm{~kg} / \mathrm{m}^{3}\right)$, and the highest $\mathrm{IC}_{50}$ value was observed for the extract obtained at the highest density $(900 \mathrm{~kg} / \mathrm{m}$ [3]). This trend may be related with the higher amount of abietadiene that is extracted at lower $\mathrm{CO}_{2}$ densities (Fig. 4), since this compound has proven insecticidal and antiparasitic activities $[48,49]$ and therefore may be an inhibitor of AChE.

Neither temperature nor the interaction parameter had a significant effect on the AChE inhibitory activity shown by the extracts (Table 3 ). Moreover, no clear relationship was observed between AChE inhibition activity and total phenolic contents, as shown in Fig. 7B. However, some studies with other plants identified the class of phenolic compounds as being responsible for AChE inhibition activity [20,22,62]. The extracts obtained at the lowest pressures, 84-136 bar, corresponding to extraction conditions 1-4 (Table 2 and Fig. 7B), presented both higher total phenolic contents and higher insecticidal activity (denoted by lower IC $_{50}$ values). However, some extracts obtained at higher density conditions (numbers 7 and 9) have likewise revealed

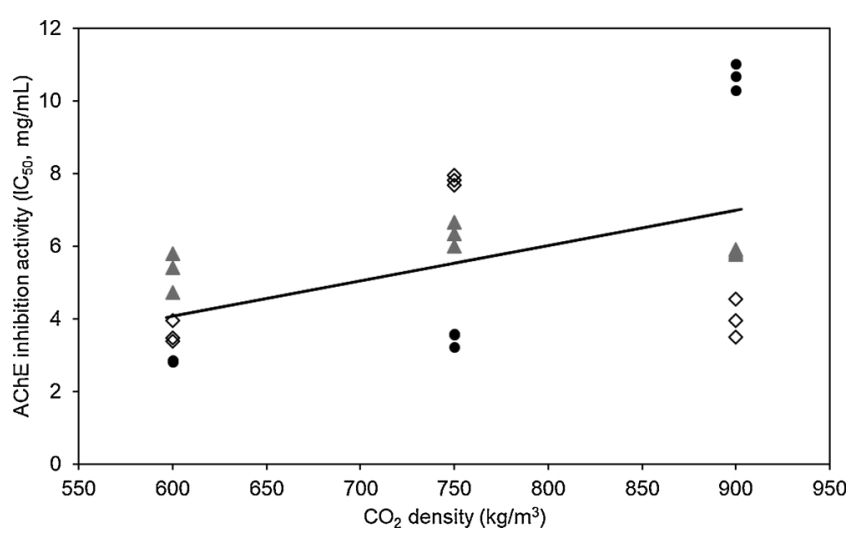

Fig. 8. Influence of solvent density $\left(\mathrm{kg} / \mathrm{m}^{3}\right)$ on AChE inhibition activity (IC $\mathrm{I}_{50}$, $\mathrm{mg} / \mathrm{mL}$ ). Straight line represents Eq. 4, and symbols represent experimental results (in triplicate) at different conditions of temperature: $35^{\circ} \mathrm{C}(\boldsymbol{\Delta}), 45^{\circ} \mathrm{C}$ $(\odot)$, and $55^{\circ} \mathrm{C}(\diamond)$.

high AChE inhibition activities, despite their low phenolic contents.

The HD extracts have also shown activity against the AChE enzyme, with the volatile oil being more active than the aqueous extract (Table 2). This finding confirms that all extracts may have potential against insects/larvae, which may be linked to the action of abietadiene, present in relatively high amounts in all extracts. Further investigations, namely the isolation of abietadiene and the evaluation of its own insecticidal potential, may confirm this hypothesis. Nevertheless, other compounds may be involved in this activity, as well as synergistic effects between several volatiles, such as compounds structurally related to abietadiene and abietic acid.

Moreover, the evaluation of the effect of these extracts directly on insects is needed to confirm the hypothesis of their insecticidal/larvicidal activity, paving the way for future development of eco-friendly strategies to manage insect diseases. The relatively high antioxidant activity of the $\mathrm{scCO}_{2}$ extracts may be an advantage of possible future formulations containing these extracts, since oxidation and degradation events are expected to be low.

\section{Conclusions}

As previously mentioned, conventional chemical insecticides are generally highly effective for controlling insects but can be harmful for the environment, as well as for human and animal health. Alternative methods for insects' management are then required, and plant extracts have tremendous potential to bring sustainability to agricultural and forestry practices. In this study, both $\mathrm{scCO}_{2}$ extraction and $\mathrm{HD}$ proved to be able to extract interesting volatile compounds from the chemical point of view. Abietadiene, the precursor of abietic acid, which is produced by conifer species as a defensive secretion against insect and pathogen attacks, was the main volatile compound in all $\mathrm{scCO}_{2}$ extracts and it was present in higher percentages in extracts obtained at lower temperatures and $\mathrm{CO}_{2}$ densities. The AChE inhibitory activity assay revealed the inhibition of this enzyme by the $\mathrm{scCO}_{2}$ extracts, which was favored by low $\mathrm{CO}_{2}$ densities. $\mathrm{IC}_{50}$ values were in the $2.83-10.7 \mathrm{mg} / \mathrm{mL}$ range. The relatively high antioxidant activity of the $\mathrm{scCO}_{2}$ extracts $(\beta$ carotene oxidation inhibitions of $42-59 \%$ ) may be an advantage of possible future formulations containing this extract, since oxidation and degradation events are reduced and shelf life is prolonged. The HD volatile oil, though also presenting inhibition of AChE activity (IC Fo $_{5}$ of $3.98 \mathrm{mg} / \mathrm{mL}$ ), showed pro-oxidant activity, which is probably related to the exposition to heat, light and oxygen that occurs during this conventional process.

Further research needs to be conducted in order to confirm the activity of the $P$. pinaster branches $\mathrm{scCO}_{2}$ extracts, namely in vivo studies to scrutinize their influence against some insects. Nevertheless, a 
contribution has been made towards the development of a possible ecofriendly insect management strategy, applying green technology and using a low-value forest residue, in consonance with current bioeconomy and biorefinery policies.

\section{CRediT authorship contribution statement}

Marisa C. Gaspar: Conceptualization, Methodology, Validation, Formal analysis, Investigation, Writing - original draft. Hermínio C. de Sousa: Validation, Writing - review \& editing. Inês J. Seabra: Methodology, Validation, Investigation, Writing - review \& editing. Mara E.M. Braga: Conceptualization, Validation, Writing - review \& editing, Supervision, Project administration.

\section{Declaration of Competing Interest}

None.

\section{Acknowledgement}

This work was financially supported by COMPETE 2020, Fundação para a Ciência e Tecnologia (FCT, Portugal), through the Programa de Atividades Conjuntas (PAC), project "MultiBiorefinery - Multi-purpose strategies for broadband agro-forest and fisheries by-products: a step forward for a truly integrated biorefinery - POCI-01-0145-FEDER016403" and through the project "New eco-friendly approaches for the biomanagement of the pinewood nematode vector at Eurasia" ECOVECTOR, POCI-01-0145-FEDER-016820 and through FCT-MEC (PEst-C/EQB/UI0102/2013). M.C. Gaspar and M.E.M. Braga acknowledge FCT for the scholarships from MultiBiorefinery project and SFRH/ BPD/101048/2014, respectively.

\section{Appendix A. Supplementary data}

Supplementary material related to this article can be found, in the online version, at doi:https://doi.org/10.1016/j.jcou.2019.11.027.

\section{References}

[1] E. Mateus, R.C. Barata, J. Zrostlíková, M.D.R. Gomes da Silva, M.R. Paiva, Characterization of the volatile fraction emitted by Pinus spp. By one- and twodimensional chromatographic techniques with mass spectrometric detection, J. Chromatogr. A 1217 (11) (2010) 1845-1855.

[2] Ö. Özgenç, S. Durmaz, G. Çelik, B. Korkmaz, N. Yaylı, Comparative phytochemical analysis of volatile organic compounds by SPME-GC-FID/MS from six coniferous and nine deciduous tree bark species grown in Turkey, South Afr. J. Bot. 113 (Supplement C) (2017) 23-28.

[3] M.A. Ibrahim, P. Kainulainen, A. Aflatuni, Insecticidal, repellent, antimicrobial activity and phytotoxicity of essential oils: with special reference to limonene and its suitability for control of insect pests, Agric. Food Sci. 10 (3) (2008) 243-259.

[4] J.U. Rehman, A. Ali, I.A. Khan, Plant based products: use and development as repellents against mosquitoes: a review, Fitoterapia 95 (Supplement C) (2014) 65-74.

[5] R.E. Lafever, B.S. Vogel, R. Croteau, Diterpenoid resin acid biosynthesis in conifers: enzymatic cyclization of geranylgeranyl pyrophosphate to abietadiene, the precursor of abietic acid, Arch. Biochem. Biophys. 313 (1) (1994) 139-149.

[6] J. Li, J. Li, Y. Gao, S. Shang, Z. Song, G. Xiao, Taking advantage of a sustainable forest resource in agriculture: a value-added application of volatile turpentine analogues as botanical pesticides based on amphipathic modification and QSAR study, ACS Sustain. Chem. Eng. 4 (9) (2016) 4685-4691.

[7] P. Hakkila, Biomass components of a tree, in: Springer Series in Wood Science (Ed.), Utilization of Residual Forest Biomass, Springer, Berlin, Heidelberg, 1989.

[8] S. Rivas, A.M. Raspolli-Galletti, C. Antonetti, V. Santos, J.C. Parajó, Sustainable conversion of Pinus pinaster wood into biofuel precursors: a biorefinery approach, Fuel 164 (Supplement C) (2016) 51-58.

[9] F. Cherubini, The biorefinery concept: using biomass instead of oil for producing energy and chemicals, Energy Convers. Manage. 51 (7) (2010) 1412-1421.

[10] B.J. Moncada, M.V. Aristizábal, A.C.A. Cardona, Design strategies for sustainable biorefineries, Biochem. Eng. J. 116 (Supplement C) (2016) 122-134.

[11] F. Macchioni, P.L. Cioni, G. Flamini, I. Morelli, S. Maccioni, M. Ansaldi, Chemical composition of essential oils from needles, branches and cones of Pinus pinea, $P$. halepensis, P. Pinaster and P. Nigra from central ltaly, Flavour Fragr. J. 18 (2) (2003) 139-143.

[12] G. Hussain Mallah, Review of the current status of insecticide resistance in insect pests of cotton and their management, Pak. J. Bot. 39 (7) (2007) 2699-2703.
[13] EPA, Recognition and Management of Pesticide Poisonings: Chapter 5 Organophosphates, 6th ed., Environmental Protection Agency, USA, 2013.

[14] I. Volf, I. Ignat, M. Neamtu, V.I. Popa, Thermal stability, antioxidant activity, and photo-oxidation of natural polyphenols, Chem. Pap. 68 (1) (2014) 121-129.

[15] R.L. Carr, N. Alugubelly, A.N. Mohammed, Chapter Five - possible mechanisms of developmental neurotoxicity of organophosphate insecticides, in: M. Aschner, L.G. Costa (Eds.), Advances in Neurotoxicology, vol. 2, Academic Press, 2018, pp. $145-188$.

[16] T.R. Fukuto, Mechanism of action of organophosphorus and carbamate insecticides, Environ. Health Perspect. 87 (1990) 245-254.

[17] R. Macholz, Organophosphorus insecticides: a general introduction (Environmental Health Criteria 63), Food/ Nahrung 32 (7) (1988) 708-708.

[18] M.B. Colović, D.Z. Krstić, T.D. Lazarević-Pašti, A.M. Bondžić, V.M. Vasić, Acetylcholinesterase inhibitors: pharmacology and toxicology, Curr. Neuropharmacol. 11 (3) (2013) 315-335.

[19] T. Nabeshima, A. Mori, T. Kozaki, Y. Iwata, O. Hidoh, S. Harada, S. Kasai, D.W. Severson, Y. Kono, T. Tomita, An amino acid substitution attributable to insecticide-insensitivity of acetylcholinesterase in a Japanese encephalitis vector mosquito, Culex tritaeniorhynchus, Biochem. Biophys. Res. Commun. 313 (3) (2004) 794-801.

[20] H. Perumalsamy, M.J. Jang, J.-R. Kim, M. Kadarkarai, Y.-J. Ahn, Larvicidal activity and possible mode of action of four flavonoids and two fatty acids identified in Millettia pinnata seed toward three mosquito species, Parasit. Vectors 8 (2015) 237.

[21] S.-M. Seo, C.-S. Jung, J. Kang, H.-R. Lee, S.-W. Kim, J. Hyun, I.-K. Park, Larvicidal and acetylcholinesterase inhibitory activities of apiaceae plant essential oils and their constituents against Aedes albopictus and formulation development, J. Agric. Food Chem. 63 (45) (2015) 9977-9986.

[22] A.M. Maazoun, T.B. Hlel, S.H. Hamdi, F. Belhadj, J.M.B. Jemâa, M.N. Marzouki, Screening for insecticidal potential and acetylcholinesterase activity inhibition of Urginea maritima bulbs extract for the control of Sitophilus oryzae (L.), J. Asia Pac. Entomol. 20 (3) (2017) 752-760.

[23] Assembleia da República, Lei n. ${ }^{\circ} 76 / 2017$ de 1 de agosto. Diário da República, 1. série - N. ${ }^{\circ} 158-17$ de agosto de 2017: Lisboa, Portugal (2017).

[24] Q. Ren, Y. Jin, Y. Hu, H. Chen, Z. Li, Rapid changes of induced volatile organic compounds in Pinus massoniana, Front. For. China 2 (4) (2007) 459-465.

[25] N.A. Gañán, A.M.A. Dias, F. Bombaldi, J.A. Zygadlo, E.A. Brignole, H.C. de Sousa, M.E.M. Braga, Alkaloids from Chelidonium majus L.: fractionated supercritical $\mathrm{CO}_{2}$ extraction with co-solvents, Sep. Purif. Technol. 165 (Supplement C) (2016) 199-207.

[26] R. Szmigielski, M. Cieslak, K.J. Rudziński, B. Maciejewska, Identification of volatiles from Pinus silvestris attractive for Monochamus galloprovincialis using a SPME-GC/MS platform, Environ. Sci. Pollut. Res. - Int. 19 (7) (2012) 2860-2869.

[27] N. Cicco, M.T. Lanorte, M. Paraggio, M. Viggiano, V. Lattanzio, A reproducible, rapid and inexpensive Folin-Ciocalteu micro-method in determining phenolics of plant methanol extracts, Microchem. J. 91 (1) (2009) 107-110.

[28] P.A. Hammerschmidt, D.E. Pratt, Phenolic antioxidants of dried soybeans, J. Food Sci. 43 (2) (1978) 556-559.

[29] G.L. Ellman, K.D. Courtney, V. Andres, R.M. Featherstone, A new and rapid colorimetric determination of acetylcholinesterase activity, Biochem. Pharmacol. 7 (2) (1961) 88-95.

[30] A. Ferreira, C. Proença, M.L.M. Serralheiro, M.E.M. Araújo, The in vitro screening for acetylcholinesterase inhibition and antioxidant activity of medicinal plants from Portugal, J. Ethnopharmacol. 108 (1) (2006) 31-37.

[31] F.X. Jervis, G. Rein, Experimental study on the burning behaviour of Pinus halepensis needles using small-scale fire calorimetry of live, aged and dead samples, Fire Mater. 40 (3) (2016) 385-395.

[32] P.T.V. Rosa, J.C. Parajó, H. Domínguez, A. Moure, B. Díaz-Reinoso, L.S. Richard, M. Toyomizu, L.J. Florusse, C.J. Peters, M. Goto, S. Lucas, M.A.A. Meireles, Supercritical and pressurized fluid extraction applied to the food industry, in: M.A.A. Meireles (Ed.), Extracting Bioactive Compounds for Food Products, Boca Raton: CRC Press, Ireland, 2008.

[33] S.M. Pourmortazavi, S.S. Hajimirsadeghi, Supercritical fluid extraction in plant essential and volatile oil analysis, J. Chromatogr. A 1163 (1-2) (2007) 2-24.

[34] R. Abad Viñas, G. Caudullo, S. Oliveira, D. de Rigo, Pinus pinaster in Europe: distribution, habitat, usage and threats, in: J. San-Miguel-Ayanz, D. de Rigo, G. Caudullo, T.H. Durrant, A. Mauri (Eds.), European Atlas of Forest Tree Species, Publication Office of the European Union, Luxembourg, 2016.

[35] F. Bertaud, C. Crampon, E. Badens, Volatile terpene extraction of spruce, fir and maritime pine wood: supercritical $\mathrm{CO}_{2}$ extraction compared to classical solvent extractions and steam distillation, Holzforschung 71 (7) (2017) 667-673.

[36] I.J. Seabra, A.M.A. Dias, M.E.M. Braga, H.C. de Sousa, High pressure solvent extraction of maritime pine bark: study of fractionation, solvent flow rate and solvent composition, J. Supercrit. Fluids 62 (2012) 135-148.

[37] E. Duquesnoy, B. Marongiu, V. Castola, A. Piras, S. Porcedda, J. Casanova, Supercritical $\mathrm{CO}_{2}$ extract from needles of Pinus nigra ssp. Laricio : combined analysis by GC, GC-MS and ${ }^{13} \mathrm{C}$ NMR, Nat. Prod. Res. 21 (9) (2007) 834-837.

[38] M.E.M. Braga, R.M.S. Santos, I.J. Seabra, R. Facanali, M.O.M. Marques, H.C. de Sousa, Fractioned SFE of antioxidants from maritime pine bark, J. Supercrit. Fluids 47 (1) (2008) 37-48.

[39] R. Pavela, M. Sajfrtová, H. Sovová, M. Bárnet, J. Karban, The insecticidal activity of Tanacetum parthenium (L.) Schultz Bip. Extracts obtained by supercritical fluid extraction and hydrodistillation, Ind. Crops Prod. 31 (3) (2010) 449-454.

[40] Y. Yamini, M. Khajeh, E. Ghasemi, M. Mirza, K. Javidnia, Comparison of essential oil compositions of Salvia mirzayanii obtained by supercritical carbon dioxide extraction and hydrodistillation methods, Food Chem. 108 (1) (2008) 341-346.

[41] G. Sodeifian, S.A. Sajadian, Investigation of essential oil extraction and antioxidant 
activity of Echinophora platyloba DC. Using supercritical carbon dioxide, J. Supercrit. Fluids 121 (Supplement C) (2017) 52-62.

[42] G. Brunner, Gas Extraction : an Introduction to Fundamentals of Supercritical Fluids and the Application to Separation Processes, Steinkopff-Verlag, Darmstadt, 1994.

[43] M.D. Burford, S.B. Hawthorne, D.J. Miller, T. Braggins, Comparison of methods to prevent restrictor plugging during off-line supercritical extraction, J. Chromatogr. A 609 (1) (1992) 321-332.

[44] M. Faccoli, G. Anfora, M. Tasin, Stone pine volatiles and host selection by Tomicus destruens (Wollaston) (Coleoptera: curculionidae, Scolytidae), Silva Lusit. 19 (2011) 61-73.

[45] M.E. Maffei, Sites of synthesis, biochemistry and functional role of plant volatiles, South Afr. J. Bot. 76 (4) (2010) 612-631.

[46] M.F. Ryan, O. Byrne, Plant-insect coevolution and inhibition of acetylcholinesterase, J. Chem. Ecol. 14 (10) (1988) 1965-1975.

[47] İ. Tümen, E.K. Akkol, H. Taştan, I. Süntar, M. Kurtca, Research on the antioxidant, wound healing, and anti-inflammatory activities and the phytochemical composition of maritime pine (Pinus pinaster Ait), J. Ethnopharmacol. 211 (Supplement C) (2018) 235-246.

[48] J. Wanner, N. Tabanca, M. Zehl, L. Jirovetz, E. Schmidt, A. Patschka, A. Ali, A. Estep, J.J. Becnel, A.Y. Li, I.A. Khan, Investigations into the chemistry and insecticidal activity of Euonymus europaeus Seed oil and methanol extract, Curr. Bioact. 11 (1) (2015) 13-22.

[49] V. Samoylenko, D.C. Dunbar, M.A. Gafur, S.I. Khan, S.A. Ross, J.S. Mossa, F.S. ElFeraly, B.L. Tekwani, J. Bosselaers, I. Muhammad, Antiparasitic, nematicidal and antifouling constituents from Juniperus berries, Phytother. Res. 22 (12) (2008) $1570-1576$.

[50] M.Z.M. Salem, A. Zeidler, M. Böhm, M.E.A. Mohamed, H.M. Ali, GC/MS Analysis of oil extractives from wood and bark of Pinus sylvestris, Abies alba, Picea abies, and Larix decidua, Bioresources 10 (4) (2015) 7725-7737.

[51] A. Nachar, A. Saleem, J.T. Arnason, P.S. Haddad, Regulation of liver cell glucose homeostasis by dehydroabietic acid, abietic acid and squalene isolated from balsam fir (Abies balsamea (L.) Mill.) a plant of the Eastern James Bay Cree traditional pharmacopeia, Phytochemistry 117 (2015) 373-379.

[52] H. Erdtman, L. Westfelt, The neutral diterpenes from pine wood resin, Acta Chem. Scand. 17 (6) (1963) 1826-1827.

[53] A.I. Lisina, A.I. Rezvukhin, V.A. Pentegova, Composition of the neutral fraction of the resin of Pinus sibirica R. Mayr, Chem. Nat. Compd. 1 (4) (1965) 193-197.

[54] V.A. Raldugin, L.I. Demenkova, V.A. Pentegova, Acid succinates of diterpene alcohols - a new type of components of conifer oleoresins, Chem. Nat. Compd. 26 (5) (1990) 594-595.

[55] H.G. Lee, T.Y. Kim, J.H. Jeon, S.H. Lee, Y.K. Hong, M.H. Jin, Inhibition of melanogenesis by abietatriene from Vitex trifolia leaf oil, Nat. Prod. Sci. 22 (4) (2016) 252-258.

[56] E. Conde, J. Hemming, A. Smeds, B.D. Reinoso, A. Moure, S. Willför, H. Domínguez, J.C. Parajó, Extraction of low-molar-mass phenolics and lipophilic compounds from Pinus pinaster wood with compressed $\mathrm{CO}_{2}$, J. Supercrit. Fluids 81 (2013) 193-199.

[57] I.J. Seabra, M.E.M. Braga, H.C. de Sousa, Statistical mixture design investigation of $\mathrm{CO}_{2}-$ Ethanol $-\mathrm{H}_{2} \mathrm{O}$ pressurized solvent extractions from tara seed coat, J. Supercrit. Fluids 64 (Supplement C) (2012) 9-18.

[58] S. Touriño, A. Selga, A. Jiménez, L. Juliá, C. Lozano, D. Lizárraga, M. Cascante, J.L. Torres, Procyanidin fractions from pine (Pinus pinaster) bark: radical scavenging power in solution, antioxidant activity in emulsion, and antiproliferative effect in melanoma cells, J. Agric. Food Chem. 53 (12) (2005) 4728-4735.

[59] N.P. Seeram, Berry fruits: compositional elements, biochemical activities, and the impact of their intake on human health, performance, and disease, J. Agric. Food Chem. 56 (3) (2008) 627-629.

[60] G. Bocquené, F. Galgani, Biological Effects of Contaminants: Cholinesterase Inhibition by Organophosphate and Carbamate Compounds, International Council for the Exploration of the Sea, France, 1998.

[61] C.D. Lee, Y.-J. Ahn, Laboratory and simulated field bioassays to evaluate larvicidal activity of Pinus densiflora hydrodistillate, its constituents and structurally related compounds against Aedes albopictus, Aedes aegypti and Culex pipiens pallens in relation to their inhibitory effects on acetylcholinesterase activity, Insects 4 (2) (2013) 217-229.

[62] V. Lattanzio, R. Terzano, N. Cicco, A. Cardinali, D.D. Venere, V. Linsalata, Seed coat tannins and bruchid resistance in stored cowpea seeds, J. Sci. Food Agric. 85 (5) (2005) 839-846.

[63] K. Abbassi, Z. Atay-Kadiri, S. Ghaout, Biological effects of alkaloids extracted from three plants of Moroccan arid areas on the desert locust, Physiol. Entomol. 28 (3) (2003) 232-236.

[64] M. Lopez, M.J. Pascual-Villalobos, Are monoterpenoids and phenylpropanoids efficient inhibitors of acetylcholinesterase from stored product insect strains? Flavour Fragr. J. 30 (1) (2015) 108-112.

[65] A. Praveena, P. Sanjayan, Inhibition of acetylcholinesterase in three insects of economic importance by linalool, a monoterpene phytochemical, Insect Pest Manage. A Curr. Scenario 1 (2011) 340-345.

[66] A. Hematpoor, S.Y. Liew, M.S. Azirun, K. Awang, Insecticidal activity and the mechanism of action of three phenylpropanoids isolated from the roots of Piper sarmentosum Roxb, Sci. Rep. 7 (1) (2017) 12576.

[67] M. Miyazawa, Y. Nakamura, Y. Ishikawa, Insecticidal sesquiterpene from Alpinic oxyphylla against Drosophila melanogaster, J. Agric. Food Chem. 48 (8) (2000) 3639-3641. 